\title{
Human lung fibroblasts secrete nerve growth factor: effect of inflammatory cytokines and glucocorticoids
}

\author{
C. Olgart*,\#, N. Frossard*
}

Human lung fibroblasts secrete nerve growth factor: effect of inflammatory cytokines and glucocorticoids. C. Olgart, N. Frossard. C) ERS Journals Ltd 2001.

ABSTRACT: Nerve growth factor (NGF) has recently been suggested to contribute to inflammation and bronchial hyperresponsiveness in asthma. However, the cell types capable of NGF production in the human lung and airways, as well as the regulatory role of pro-inflammatory cytokines and of glucocorticoids on NGF secretion in pulmonary cells, have not been described.

Human pulmonary fibroblasts were cultured in the presence or absence of either

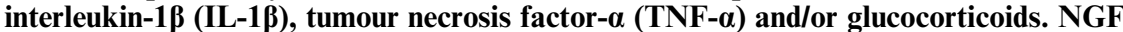
secretion was measured by enzyme-linked immunosorbent assay.

The human pulmonary fibroblasts constitutively secreted NGF in vitro. The rate of NGF secretion was shown to be cell density-dependent, since higher NGF secretion was detected in preconfluent cells, i.e. ones with less established cell-to-cell contact $\left(41.0 \pm 5.0 \mathrm{pg} \cdot 10^{-6}\right.$ cells at $80 \%$ confluence), than cells in higher densities $\left(8.2 \pm 3.4 \mathrm{pg} \cdot 10^{-6}\right.$ cells at $100 \%$ confluence). Stimulation with the pro-inflammatory cytokines IL-1 $\left(0.3-30 \mathrm{U} \cdot \mathrm{mL}^{-1}\right)$ or TNF- $\alpha\left(0.1-30 \mathrm{ng} \cdot \mathrm{mL}^{-1}\right)$ dose- and timedependently $(8-72 \mathrm{~h}$ ) elevated the NGF secretion (effective concentration causing $50 \%$ of the maximum response $(E C 50)=2.9 \mathrm{U} \cdot \mathrm{mL}^{-1}$ and $1.0 \mathrm{ng} \cdot \mathrm{mL}^{-1}$, respectively). Treatment with the glucocorticoid budesonide $\left(10^{-7} \mathrm{M}\right)$ markedly reduced the constitutive secretion of NGF by $42 \%$, and attenuated the cytokine-stimulated NGF secretion to the same level.

In conclusion, human lung fibroblasts may serve as a source of nerve growth factor in the lung, positively regulated by the asthma-associated and pro-inflammatory cytokines interleukin- $1 \beta$ and tumour necrosis factor- $\alpha$, and negatively regulated by the antiinflammatory glucocorticoids.

Eur Respir J 2001; 18: 115-121.
*Institut National de la Santé et de la Recherche Médicale (INSERM) U425, Neuroimmunopharmacologie Pulmonaire, Faculté de Pharmacie, Université Louis Pasteur Strasbourg I, Illkirch Cedex, France. " Dept of Medicine, Division of Respiratory Medicine, Karolinska Hospital, 17176 Stockholm, Sweden.

Correspondence: N. Frossard, INSERM U425, Neuroimmunopharmacologie Pulmonaire, Faculté de Pharmacie, Université Louis Pasteur Strasbourg I, B.P. 24, 67401 Illkirch Cedex, France. Fax: 33390244309

Keywords: Airway

glucocorticoid

inflammation

interleukin- $1 \beta$

nerve growth factor

Received: August 82000

Accepted after revision January 25 2001

The project was funded by INSERM C. Olgart was supported by the Swedish MRC, T. and R. Söderberg's Foundations, $\mathrm{E}$ and $\mathrm{E}$. Fernström's Foundation, and Comité Départemental du Bas-Rhin Contre les Maladies Respiratoires et la Tuberculose, UCB Institute of Allergy, Brussels, Belgium.
The neurotrophin nerve growth factor (NGF), in addition to its essential activity on nerve growth and survival [1, 2], has recently been shown to function as an important inflammatory mediator. As evidenced from animal studies, NGF may contribute to the development of airway hyperresponsiveness [3 -5] and to an increased sensory and sympathetic innervation in the lung [4], and it may evoke a phenotypic change of airway sensory neurones [4]. NGF also has a profound effect on cells of the immune system, many of which are critically important in the development of pulmonary inflammation and asthma-related symptoms. Hence, NGF increases the number of mast cells in peripheral tissue [6] and promotes mast cell differentiation [7] and survival [8]. In addition, NGF stimulates lymphocyte survival, proliferation and differentiation, and it enhances eosinophil survival and cytotoxicity [9]. Furthermore, NGF stimulates mast cell degranulation and mediator upregulation and release $[1,2,10]$; it also enhances mediator release from various other inflammatory cells including basophils, eosinophils, neutrophils, macrophages, monocytes, and T-cells $[1,2,9,10]$.

Apart from the lung and airways, a variety of cell sources have been studied and shown to synthesize and secrete NGF. Among these are cells of the immune system, including mast cells [11], basophils, eosinophils, lymphocytes, monocytes, macrophages $[1,2,9,10]$, as well as structural cells, such as fibroblasts and vascular smooth muscle cells of various origins $[1,2,10]$. However, information about NGF secretion from cells of the lung and airways is scanty.

In the present study, it has been hypothesized that the lung fibroblast may be a source of NGF in humans, and the regulation of NGF secretion by the pro-inflammatory cytokines and asthma-associated cytokines interleukin-1 $\beta$ (IL-1 $\beta$ ) and tumour necrosis 
factor- $\alpha(\mathrm{TNF}-\alpha)$, and by the anti-inflammatory glucocorticoids has been studied.

\section{Material and methods}

\section{Primary culture of human lung fibroblasts}

Human lung-derived fibroblasts were obtained by the explant technique as previously described $[12,13]$. Macroscopically normal human lung tissue was obtained at thoracotomy for bronchial carcinoma. Donors had no diagnosed allergy, pulmonary fibrosis or emphysema. One suffered from chronic obstructive pulmonary disease. The lung tissue from each donor was cut into fragments of $0.5-2 \mathrm{~mm}^{3}$. Fragments were washed three times for $10 \mathrm{~min}$ each at $37^{\circ} \mathrm{C}$ with Eagle's minimum essential medium (MEM), supplemented with $10 \%$ foetal bovine serum (FBS), MEM nonessential amino acids (1:100), L-glutamine $(2 \mathrm{mM})$, penicillin $\left(150 \mathrm{U} \cdot \mathrm{mL}^{-1}\right)$, streptomycin $\left(150 \mu \mathrm{g} \cdot \mathrm{mL}^{-1}\right)$, gentamicin $\left(25 \mu \mathrm{g} \cdot \mathrm{mL}^{-1}\right)$, amphotericin $\mathrm{B}$ (Fungizone $\mathrm{R}$, $1 \mu \mathrm{g} \cdot \mathrm{mL}^{-1}$ ) (all products from Gibco BRL, Cergy Pontoise, France). They were plated onto $35-\mathrm{mm}$ tissue culture dishes (Costar, Cambridge, MA, USA), left for $10 \mathrm{~min}$ at room temperature to facilitate explant-adhesion, and subsequently cultured in the same medium at $37^{\circ} \mathrm{C}$ in a humidified air containing 5\% carbon dioxide $\left(\mathrm{CO}_{2}\right)$, with the medium changed twice a week. The explants were removed after $2-3$ weeks. The cells grown out from the explants reached confluence within 1-2 additional weeks. They were rinsed in Hank's balanced salt solution (HBSS; Gibco BRL), trypsinized (Trypsine-ethylene diamine tetra-acetic acid (EDTA), Gibco BRL) for $3 \mathrm{~min}$, centrifuged and resuspended in a medium that consisted of MEM supplemented with 10\% FBS, MEM nonessential amino acids (1:100), L-glutamine ( $2 \mathrm{mM})$, penicillin $\left(50 \mathrm{U} \cdot \mathrm{mL}^{-1}\right)$, streptomycin $\left(50 \mu \mathrm{g} \cdot \mathrm{mL}^{-1}\right)$, and replated in $25 \mathrm{~cm}^{2}$ flasks (Costar). The fibroblasts were subsequently split 1:4 at confluence and cultured in $75 \mathrm{~cm}^{2}$ culture flasks (Costar) in a growth culture medium for the fibroblasts based on Dulbecco's modified Eagle's medium (DMEM/F12) (1:1) supplemented with 10\% FBS, MEM nonessential amino acids $(1: 100)$, L-glutamine $(2 \mathrm{mM})$, penicillin $\left(50 \mathrm{U} \cdot \mathrm{mL}^{-1}\right)$, streptomycin $\left(50 \mu \mathrm{g} \cdot \mathrm{mL}^{-1}\right)$, and insulin $\left(5 \mu \mathrm{g} \cdot \mathrm{mL}^{-1}\right)$ (Lilly, Saint-Cloud, France). Cells were used for experimentation at the sixth or seventh passage. Cells were characterized as fibroblasts morphologically and by immunocytochemistry using a monoclonal mouse antihuman fibroblast antibody (5B5) that reacts with the $\beta$-subunit of prolyl-4hydroxylase and the disulphide-isomerase (Dako, Trappes, France).

\section{Experimental protocol}

All experiments were performed on cells cultured in growth culture medium (DMEM/F12, 10\% FBS) and starved $(24 \mathrm{~h})$ in a low FBS $(0.3 \%)$-containing, insulin-free DMEM/F12 medium in $25 \mathrm{~cm}^{2}$ flasks.
Cell growth and density-dependent secretion of NGF was determined in two different sets of experiments. First, cells were seeded at various densities $\left(4,000,12,000\right.$ or $\left.24,000 \mathrm{cells} \cdot \mathrm{cm}^{-2}\right)$, kept in growth conditions for 2 days and starved for $24 \mathrm{~h}$ before sampling of the cell supernatant at $24 \mathrm{~h}$. Secondly, NGF secretion was studied after a 24-h starvation period on cells seeded at $4,000 \mathrm{cells} \cdot \mathrm{cm}^{-2}$ and cultured for 1-8 days in the presence or absence of IL-1 $\beta$ $\left(10 \mathrm{U} \cdot \mathrm{mL}^{-1}\right)$ (Boehringer-Mannheim $\mathrm{GmbH}$, Germany). Cells reached $80 \%$ confluence after a growth period of 4 days, and confluence after 6 days. A 4-day culture of 4,000 seeded cells $\cdot \mathrm{cm}^{-2}$, corresponding to a state of $80 \%$ confluence, with a 24 -h starvation period was chosen for further experiments on the regulation of NGF secretion.

The time-dependent secretion pattern of NGF was studied in the presence or absence of IL-1 $\beta$ $\left(10 \mathrm{U} \cdot \mathrm{mL}^{-1}\right)$ incubated for $2,8,24,48$ or $72 \mathrm{~h}$. The dose-dependent effect of IL-1 $\beta$ and TNF- $\alpha$ was studied by stimulating cells with increasing concentrations of either IL- $1 \beta\left(0.3-30 \mathrm{U} \cdot \mathrm{mL}^{-1}\right)$, TNF- $\alpha(0.1-$ $30 \mathrm{ng} \cdot \mathrm{mL}^{-1}$ ) (Prepro Tech Inc., Rocky Hill, NJ, USA) or both for $24 \mathrm{~h}$. The effect of glucocorticoids was studied on cells treated with IL-1 $\beta\left(10 \mathrm{U} \cdot \mathrm{mL}^{-1}\right)$, TNF- $\alpha$ $\left(10 \mathrm{ng} \cdot \mathrm{mL}^{-1}\right)$ or saline for $24 \mathrm{~h}$ in the absence or presence of budesonide $\left(10^{-7} \mathrm{M}\right)$ (AstraZeneca, Lund, Sweden), dexamethasone $\left(10^{-6} \mathrm{M}\right)$ (Sigma Chemical Company, St Louis, MO, USA), or of solvent. The glucocorticoids or solvents were added at the same time as IL- $1 \beta$, TNF- $\alpha$ or saline.

In all experiments, cell supernatants were collected, kept on ice, centrifuged $\left(4^{\circ} \mathrm{C}, 1,200 \mathrm{rpm}, 5 \mathrm{~min}\right)$ and stored at $-20^{\circ} \mathrm{C}$ until analysis. Cells were rinsed with HBSS, trypsinized, and counted in a Neubauer chamber to determine the total cell number. None of the cytokines or glucocorticoids had any effect on cell number. Cell viability was assessed using trypan blue dye exclusion. Experiments were performed in duplicates on cell material from at least $3-5$ different subjects.

Determination of nerve growth factor by enzymelinked immunosorbent assay

NGF secreted into the supernatant of control and treated fibroblasts was quantified with a commercial NGF-specific, highly sensitive, two-site enzyme-linked immunosorbent assay (ELISA)-kit according to the procedure indicated by the manufacturer (Promega, Madison, WI, USA). Briefly, 96-well immunoplates (MaxiSorp $\mathrm{IM}$, Nunc, Roskilde, Denmark) were coated with a polyclonal goat antihuman NGF antibody in a coating buffer ( $25 \mathrm{mM}$ carbonate buffer, $\mathrm{pH} 9.7$ ). After an overnight incubation at $4{ }^{\circ} \mathrm{C}$, plates were washed $(20 \mathrm{mM}$ Tris- $\mathrm{HCl}, 150 \mathrm{mM} \mathrm{NaCl}$ with $0.05 \%$ $(\mathrm{v} / \mathrm{v})$ Tween $(\mathrm{R})-20)$ and incubated in a blocking buffer (supplied by the manufacturer) for $1 \mathrm{~h}$. The supernatants and the standard recombinant human NGF dilutions in the low $(0.3 \%)$ FBS-medium were incubated into the wells at $37^{\circ} \mathrm{C}$ in a humid chamber for at least $6 \mathrm{~h}$, and washed. Rat monoclonal anti-NGF antibody $\left(0.25 \mu \mathrm{g} \cdot \mathrm{mL}^{-1}\right)$ was added for an overnight incubation at $4^{\circ} \mathrm{C}$, and washed. Antirat horseradish 
peroxidase-conjugated immunoglobulin-G (IgG) was added for a $2.5-\mathrm{h}$ incubation period. Finally, the substrate $\left(0.02 \% \quad 3,3^{\prime}, 5,5^{\prime}\right.$-tetramethylbenzidine and $0.01 \%$ hydrogen peroxidase) was added. The colorimetric reaction was stopped after $10 \mathrm{~min}$ with $1 \mathrm{M}$ phosphoric acid, and the optical density was measured at $450 \mathrm{~nm}$. All measurements were performed in duplicate. The technique allowed detection of NGF in the range of $3.9-500 \mathrm{pg} \cdot \mathrm{mL}^{-1}$.

\section{Expression of results and statistical analysis}

Data were expressed as mean \pm SEM either in $p g$ $\mathrm{NGF} \cdot \mathrm{mL}^{-1}$ of culture supernatant, in pg NGF per $10^{6}$ cells, or as a percentage of the control secretion (solvent). The tested populations followed the Gaussian distribution as tested by the method of Kolmogorov and Smirnov. Differences between groups were analysed with an unpaired, two-tailed t-test, or a oneway analysis of variance followed by Tukey-Kramer post-test when appropriate (GraphPad InStat, GraphPad Software, San Diego, CA, USA). Values of $\mathrm{p}<0.05$ were considered significant.

\section{Results}

\section{Cell density-related secretion of nerve growth factor}

NGF was secreted by lung fibroblasts in culture, as evidenced by NGF protein measurement in the cell supernatants. The cell density-dependent secretion pattern of NGF was first studied after various seeding densities $\left(24,000,12,000\right.$ and 4,000 cells $\left.\cdot \mathrm{cm}^{-2}\right)$ at day 2 . Cells seeded at 24,000 cells $\cdot \mathrm{cm}^{-2}$ reached confluence after 2 days and secreted $7.0 \pm 1.0 \mathrm{pg}$ NGF per $10^{6}$ cells per $24 \mathrm{~h}$. Cells seeded at $12,000(\sim 80 \%$ confluence $)$ and 4,000 (subconfluent) cells $\cdot \mathrm{cm}^{-2}$ secreted 2.7$(\mathrm{p}<0.001)$ and 9.4-times $(\mathrm{p}<0.001)$ more basal NGF per $10^{6}$ cells per $24 \mathrm{~h}$, respectively. A seeding density of 4,000 cells $\cdot \mathrm{mL}^{-1}$ was chosen for further experiments.

Although the NGF levels accumulating in the supernatants increased from day 1 to day 4 of culture $\left(7.8 \pm 0.8-12.2 \pm 1.5 \mathrm{pg} \cdot \mathrm{mL}^{-1}\right.$ per $\left.24 \mathrm{~h}, \mathrm{p}<0.05\right)$, a significant and progressive decreased secretion of NGF was observed after normalization to the cell number $(p<0.001)$ (fig. 1a). A higher NGF secretion per $10^{6}$ cells was detected in preconfluent cells, i.e. with less established cell-to-cell contact (e.g. $41.0 \pm$ $5.0 \mathrm{pg} \cdot 10^{-6}$ cells at $80 \%$ confluence, day 4$)$, than in cells with higher densities $\left(8.2 \pm 3.4\right.$ pg per $10^{6}$ cells at $100 \%$ confluence, day 6 ). A 27.8 -fold difference was observed between the maximal and the minimal secretion $\left(161.3 \pm 20.2\right.$ and $5.8 \pm 2.0 \mathrm{pg}$ per $10^{6}$ cells per $24 \mathrm{~h}$ at day 1 and day 8 , respectively).

\section{Effect of interleukin- $1 \beta$ and tumour necrosis factor- $\alpha$ on nerve growth factor secretion}

IL-1 $\beta\left(10 \mathrm{U} \cdot \mathrm{mL}^{-1}\right)$ induced a significant increase in NGF secretion from day 2 to day 8 of culture (fig. 1a). Maximal increase was observed at day 4 (2.9fold) (fig. 1a), which was the time used for further
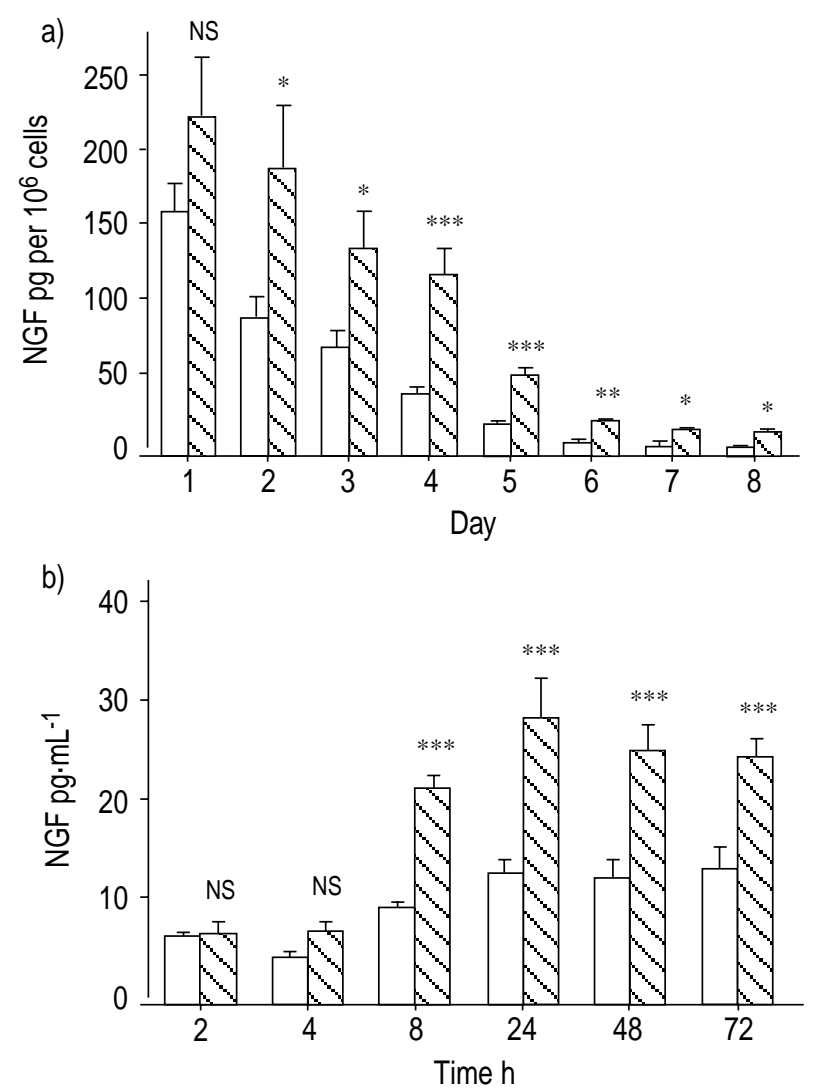

Fig. 1. - a) Growth phase-dependent secretion of nerve growth factor (NGF) from human lung fibroblasts in primary culture. Secreted NGF was determined by enzyme-linked immunosorbent assay in cell supernatants after an accumulation period of $24 \mathrm{~h}$ in the absence $(\square)$ or in the presence $(\nabla)$ of interleukin-1 $\beta$ (IL-1 $\beta$ ) $\left(10 \mathrm{U} \cdot \mathrm{mL}^{-1}\right)$ on cells kept in growth conditions $1-8$ days. Values are normalized to cell number and represent the mean \pm SEM, calculated from duplicate experiments performed on fibroblasts from five different patients. b) Time-dependent basal ( $\square$ ) and IL-1 $\beta$ $\left(10 \mathrm{U} \cdot \mathrm{mL}^{-1}\right)$-stimulated $(\nabla)$ nerve growth factor secretion from human lung fibroblasts in primary culture. Values are mean \pm SEM calculated from duplicate experiments performed on fibroblasts from five different patients. NS: nonsignificant as compared with respective control. *: $\mathrm{p}<0.05$; **: $\mathrm{p}<0.01$; ***: $\mathrm{p}<0.001$ as compared with respective controls.

experiments. Hence, a growth period of 4 days with a seeding density of 4,000 cells $\cdot \mathrm{mL}^{-1}$ and a $24 \mathrm{~h}$ starvation period was chosen for all other experiments studying regulation of NGF secretion.

At day 4, a significant and time-dependent accumulation of NGF in the cell supernatant was observed $2-24 \mathrm{~h}\left(6.9 \pm 0.4-13.2 \pm 1.5 \mathrm{pg} \cdot \mathrm{mL}^{-1}, \mathrm{p}<0.05\right.$; fig. $\left.1 \mathrm{~b}\right)$, and a stable NGF secretion was detected $24-72 \mathrm{~h}$ (fig. 1b). IL-1 $\beta \quad\left(10 \mathrm{U} \cdot \mathrm{mL}^{-1}\right)$ induced a significant enhancement of NGF secretion $8-72 \mathrm{~h}$, maximal at 8 and 24 h (2.2-fold; fig. 1b).

IL-1 $\beta\left(0.3-30 \mathrm{U} \cdot \mathrm{mL}^{-1}\right)$ and TNF- $\alpha(0.1-30$ $\left.\mathrm{ng} \cdot \mathrm{mL}^{-1}\right)$ both evoked a dose-dependent enhancement of NGF secretion at $24 \mathrm{~h}$ (fig. 2), with a maximal increase of $124 \%$ for IL- $1 \beta\left(30 \mathrm{U} \cdot \mathrm{mL}^{-1}\right)(\mathrm{EC} 50=$ $\left.2.9 \mathrm{U} \cdot \mathrm{mL}^{-1}\right)$ and of $114 \%$ for TNF- $\alpha\left(30 \mathrm{ng} \cdot \mathrm{mL}^{-1}\right)$ $\left(\mathrm{EC} 50=1.0 \mathrm{ng} \cdot \mathrm{mL}^{-1}\right)$. When combining both cytokines, IL-1 $\beta\left(0.1-3 \mathrm{U} \cdot \mathrm{mL}^{-1}\right)$ and TNF- $\alpha\left(0.1-1 \mathrm{ng} \cdot \mathrm{mL}^{-1}\right)$, an additive stimulatory effect was observed on NGF secretion (fig. 3). 

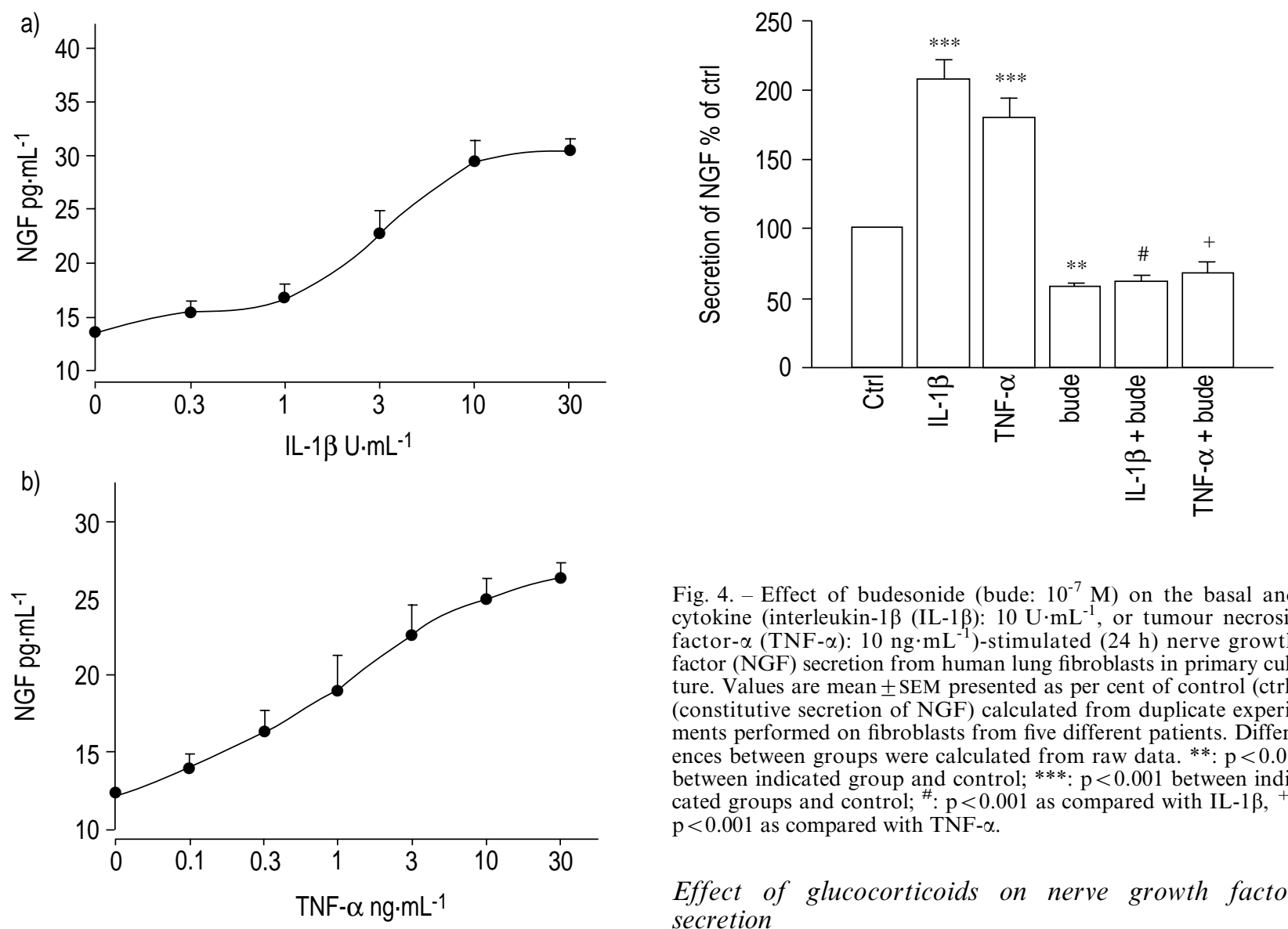

Fig. 2. - Dose-dependent stimulated (24 h) secretion of nerve growth factor (NGF) by a) interleukin-1 $\beta$ (IL-1 $\beta$ ) and $b$ ) tumour necrosis factor- $\alpha$ (TNF- $\alpha$ ) in human lung fibroblasts in primary culture. Values are mean \pm SEM calculated from duplicate experiments performed on fibroblasts from three different patients.

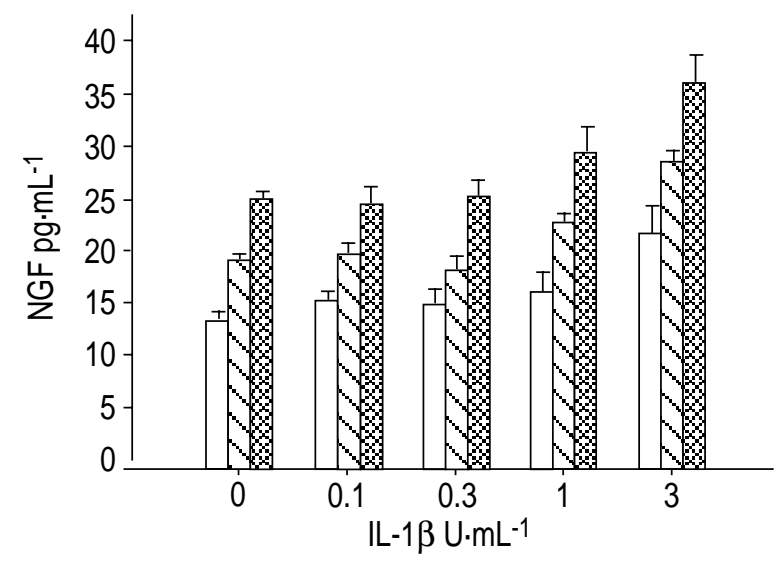

Fig. 3. - Additive stimulatory effect of interleukin-1 $\beta$ (IL-1 $\beta$ ) and tumour necrosis factor- $\alpha$ (TNF- $\alpha)(24 \mathrm{~h})$ on nerve growth factor (NGF) secretion from human lung fibroblasts in primary culture. Values are mean \pm SEM calculated from duplicate experiments performed on fibroblasts from three different patients. $\square$ : control; $\square$ : TNF- $\alpha\left(0.1 \mathrm{ng} \cdot \mathrm{mL}^{-1}\right)$; 잢: TNF- $\alpha\left(1 \mathrm{ng} \cdot \mathrm{mL}^{-1}\right)$.
Fig. 4. - Effect of budesonide (bude: $10^{-7} \mathrm{M}$ ) on the basal and cytokine (interleukin-1 $\beta$ (IL-1 $\beta$ ): $10 \mathrm{U} \cdot \mathrm{mL}^{-1}$, or tumour necrosis factor- $\left.\alpha(\mathrm{TNF}-\alpha): 10 \mathrm{ng} \cdot \mathrm{mL}^{-1}\right)$-stimulated $(24 \mathrm{~h})$ nerve growth factor (NGF) secretion from human lung fibroblasts in primary culture. Values are mean \pm SEM presented as per cent of control (ctrl) (constitutive secretion of NGF) calculated from duplicate experiments performed on fibroblasts from five different patients. Differences between groups were calculated from raw data. ${ }^{* *}: \mathrm{p}<0.01$ between indicated group and control; ***: $\mathrm{p}<0.001$ between indicated groups and control; ${ }^{\#}: \mathrm{p}<0.001$ as compared with IL-1 $\beta,{ }^{+}$: $\mathrm{p}<0.001$ as compared with TNF- $\alpha$.

Effect of glucocorticoids on nerve growth factor secretion

The influence of glucocorticoids was studied on the constitutive and cytokine-stimulated NGF secretions. Budesonide $\left(10^{-7} \mathrm{M}\right)$ significantly reduced the constitutive secretion of NGF by $42 \%$, and attenuated the IL-1 $\beta\left(10 \mathrm{U} \cdot \mathrm{mL}^{-1}\right)-$ and TNF- $\alpha\left(10 \mathrm{ng} \cdot \mathrm{mL}^{-1}\right)-$ stimulated secretion of NGF by 70 and $62 \%$, respectively (fig. 4). A similar effect was observed with dexamethasone $\left(10^{-6} \mathrm{M}\right)$, with a reduction of the constitutive secretion by $39 \%(\mathrm{p}<0.05)$, and of the IL$1 \beta \quad\left(10 \mathrm{U} \cdot \mathrm{mL}^{-1}\right)$-stimulated secretion by $72 \%$ $(\mathrm{p}<0.001$; not shown). Solvents had no effect on NGF secretion.

\section{Discussion}

The present study provides evidence that the human lung fibroblasts in culture constitutively produce NGF, whose levels are increased in response to the pro-inflammatory and asthma-associated cytokines IL-1 $\beta$ and TNF- $\alpha$. In addition, the glucocorticoids induce a decrease in both the constitutive and the cytokine-stimulated NGF secretion by the lung fibroblasts.

The present study demonstrates that NGF may be secreted by cultured structural cells from the human lung, i.e. the pulmonary fibroblast. This finding is in agreement with studies showing that the human fibroblast from other origins, e.g. the skin, expresses and secretes NGF [14, 15]. However, a differential 
regulation of NGF expression has been reported in the same cell type, i.e. the fibroblast, derived from different tissues and at different stages of human development $[15,16]$. For instance, CARTWRIGHT et al. [15] failed to detect any expression of NGF messenger ribonucleic acid (mRNA) in human embryonic lung fibroblasts, whereas expression was observed in postembryonic cutaneous fibroblasts. In the light of the present study, this suggests that different molecular mechanisms may regulate the human NGF gene expression or transcription during life or differentiation.

Interestingly, the present data show that NGF secretion by the human lung fibroblast is not constant during culture. It is high at the very early stages of cell culture, lowering with the increase in cell number, and reaching the lowest level after confluence. It was clearly demonstrated that this phenomenon is cell density-dependent, since decreasing secretion of NGF was obtained with cells seeded at increasing densities. This suggests that cells with a less established cell-tocell contact secrete more NGF than cells reaching confluence. These results are in full agreement with results from studies of NGF secretion in mouse astrocytes [17, 18], epithelial cells [19] and human cutaneous fibroblasts [14], where a cell densitydependent secretion has been reported.

In addition, the presented data provide evidence that the lung fibroblast secretes elevated levels of NGF when stimulated with the pro-inflammatory cytokines IL-1 $\beta$ and TNF- $\alpha$. This increased secretion was time- and dose-dependent. These results are in agreement with data obtained from other structural cells, such as the rat sciatic nerve-derived fibroblasts [20] or the human skin fibroblasts [21], where an enhanced NGF secretion is described in response to IL-1 $\beta$ and/or TNF- $\alpha$. Additionally, it is shown that the combination of both IL- $1 \beta$ and TNF- $\alpha$ evokes an additive stimulatory effect on NGF secretion by human lung fibroblasts. This latter finding is not in full agreement with observations of a synergistic stimulatory effect of the combination of both cytokines on NGF secretion in Swiss 3T3 cells [22]. These diverse results may reflect different regulation and cross-talk of the signal transduction pathways stimulated by TNF- $\alpha$ and IL-1 $\beta$ in the different cell types. This is in agreement with the notion that the regulation of NGF secretion occurs in a cell- and tissue-specific manner, where a similar stimulus may have various effects in different cells [16]. Thus, when describing the control of NGF secretion by mediators of inflammation, direct testing of organ- and tissuespecific cells is prompted.

Excessive amounts of IL-1 $\beta$ and TNF- $\alpha$ have been implicated in the pathogenesis of a number of inflammatory conditions in the lung and airways, including asthma [23]. Furthermore, a number of cells involved in the inflammatory response, like the macrophages, mast cells or lymphocytes, are important sources of IL-1 $\beta$ and TNF- $\alpha$. They are found in close proximity to the fibroblasts, and thus might be capable of stimulating NGF secretion in situ. Indeed, the doses of both cytokines used are within their biological range of action when expressed in airway inflammation [24], as well as in other in vitro cell systems [20, 21]. Thus, the present results support a potentially important role for IL-1 $\beta$ and TNF- $\alpha$ to stimulate fibroblast secretion of NGF in pulmonary inflammation. This increases the list of potentially IL$1 \beta$ - and TNF- $\alpha$-responsive genes in the lung. However, further studies are necessary to reveal whether IL-1 $\beta$ and TNF- $\alpha$ are involved in modulating lung and airway function through the stimulation of $\mathrm{NGF}$ production.

The enhanced secretion of NGF by the proinflammatory cytokines, IL-1 $\beta$ and TNF- $\alpha$, suggests that elevated levels of NGF during pulmonary inflammation are likely. Recent studies have revealed elevated serum levels of NGF in subjects suffering from asthma, especially patients with severe allergic asthma [25]. Also, higher levels of NGF were detected in the bronchoalveolar lavage from asthmatics as compared with healthy individuals [10, 26], as well as after allergen challenge in asthmatics [27]. NGF secretion most likely originates from lung and airway cells, like the fibroblast as a structural cell and/or the infiltrated inflammatory cells, such as the mast cells, eosinophils and/or lymphocytes, which are other potential sources of NGF in the lung and airways. The capacity of lung fibroblasts to produce elevated levels of NGF upon activation with IL-1 $\beta$ and TNF- $\alpha$ suggests that these cells may participate in the regulation of local inflammatory events. Hence, the fibroblast may not only be an end-target cell for the effect of mediators, but also a source of mediators capable of participating in further priming of surrounding inflammatory cells.

At present, little is known about the role of NGF in human lung and airways. NGF has been suggested to function as a paracrine survival factor for immune/ inflammatory cells, as well as for peripheral neurones $[1,2]$. Indeed, recent studies have revealed that inflammatory/immune cells express the high-affinity cell surface receptor for NGF, tyrosine kinase receptor $A(\operatorname{Trk} A)[1,2,9-11]$, and that peripheral neurones express both the high- and low-affinity receptor for NGF, TrkA and a protein with the molecular weight of $\sim 75,000 \mathrm{kDa}(\mathrm{p} 75)$, respectively $[1,2,9,10]$. Inflammatory/immune cells as well as neurones, may thus be a target for NGF released in the airways. In addition, NGF has recently been reported to contribute to the development of airway hyperresponsiveness [3,5] through a neurokinin-1 receptor-dependent mechanism. This neuronal "sensitization" may be a direct effect of NGF on the sensory nerves, or have an indirect component involving some inflammatory cells such as the mast cell $[10,11]$ or the T-helper 2 (Th2) cell $[3,10]$. Hence, there is increasing evidence for a potential involvement of NGF in a variety of pathological conditions of the lung and airways.

As corticosteroids are known to have potent antiinflammatory effects and are clinically effective in suppressing inflammation in lung and airways, it was also determined whether budesonide and dexamethasone were capable of inhibiting secretion of NGF by human lung fibroblasts. The present study found that the constitutive NGF secretion was markedly decreased. In addition, the IL-1 $\beta$ - and 
TNF- $\alpha$-stimulated NGF secretion was inhibited to the same low level. These findings are in agreement with studies showing that corticosteroids also inhibit the production of several other pro-inflammatory factors, such as IL-6, IL-8, IL-11, granulocyte macrophagecolony stimulating factor (GM-CSF), or regulated on activation, normal $\mathrm{T}$-cell expressed and secreted (RANTES) from fibroblasts [28]. Although an inhibitory effect of glucocorticoids is reported on NGF expression by, for example, the murine fibroblast cell line L929 or rat sciatic nerve-derived fibroblasts [10, 29], a stimulatory effect of glucocorticoids may be at hand in other cellular systems such as hippocampal neurones $[1,2]$. The presented data suggest that glucocorticoids may inhibit excessive NGF secretion during inflammatory conditions, and that the human lung fibroblast might be an important therapeutic target for the anti-inflammatory action of glucocorticoids [28]. As reported in rat fibroblasts, the inhibitory effects of glucocorticoids on NGF secretion may involve a decreased NGF mRNA stability [29], or a transcriptional repression, as suggested by LINDHOLM et al. [29]. This last mechanism might involve the interaction between glucocorticoids and the transcription factor activation protein-1 (AP-1), whose binding site is present in the promoter region of the human NGF gene [30]. However, this involvement has to be confirmed in human lung fibroblasts.

In conclusion, the present findings suggest that the human pulmonary fibroblasts may be an important source of nerve growth factor and that the proinflammatory and asthma-associated cytokines interleukin- $1 \beta$ and tumour necrosis factor- $\alpha$, may enhance this nerve growth factor secretion. Taking into account the newly discovered effects of nerve growth factor linked to asthma-associated symptoms in animals [3, 5], the fibroblast may, through stimulated nerve growth factor secretion, play an active role in airway inflammation. Furthermore, the anti-inflammatory glucocorticoids reduce the enhanced production of nerve growth factor. This study, thus, adds some new elements in the mechanism of action of the anti-inflammatory glucocorticoids, suppressing excessive nerve growth factor secretion from lung fibroblasts.

\begin{abstract}
Acknowledgements. The authors thank G. Massard (Service de Chirurgie Thoracique, Hôpitaux Universitaires de Strasbourg, France) and B. Gasser (Institut d'Anatomie Pathologique, Hôpitaux Universitaires de Strasbourg, France) for kindly providing us with lung samples, and M-E. Behra, C. Duvernelle and E. Mathieu for their generous help with the initial experimentation and primary cell cultures. The authors also wish to acknowledge R. Brattsand, AstraZeneca, Lund, Sweden for the kind gift of budesonide.
\end{abstract}

\section{References}

1. Levi-Montalcini R, Skaper SD, Dal Toso R, Petrelli L, Leon A. Nerve growth factor: from neurotrophin to neurokine. Trends Neurosci 1996; 19: 514-520.
2. Aloe L, Bracci-Laudiero L, Bonini S, Manni L. The expanding role of nerve growth factor: from neurotrophic activity to immunologic disease. Allergy 1997; 52: $883-994$.

3. Braun A, Appel E, Baruch R, et al. Role of nerve growth factor in a mouse model of allergic airway inflammation and asthma. Eur J Immunol 1998; 28: 3240-3251.

4. Hoyle GW, Graham RM, Finkelstein JB, Nguyen K-PT, Gozal D, Friedman M. Hyperinnervation of the airways in transgenic mice overexpressing nerve growth factor. Am J Respir Cell Mol Biol 1998; 18: $149-157$.

5. de Vries A, Dessing MC, Engels F, Henricks PAJ, Nijkamp FP. Nerve growth factor induces a neurokinin-1 receptor-mediated airway hyperresponsiveness in guinea pigs. Am J Respir Crit Care Med 1999; 159: $1541-1544$.

6. Aloe L, Levi-Montalcini R. Mast cell increase in tissues in neo-natal rats injected with the nerve growth factor. Brain Res 1977; 133: 358 - 363.

7. Matsuda $\mathrm{H}$, Kannan $\mathrm{Y}$, Ushio $\mathrm{H}$, et al. Nerve growth factor induces development of connective tissue-type mast cells in vitro from murine bone marrow cells. J Exp Med 1991; 174: 7-14.

8. Bullock ED, Johnson EM. Nerve growth factor induces the expression of certain cytokine genes and bcl-2 in mast cells. Potential role in survival promotion. J Biol Chem 1996; 271: 27500-27508.

9. Simone MD, De Santis S, Vigneti E, Papa G, Amadori S, Aloe L. Nerve growth factor: a survey of activity on immune and hematopoietic cells. Hematol Oncol 1999; 17: 1-10.

10. Olgart C, Frossard N. Nerve growth factor and asthma. Eur Respir Rev 2000; 10: 326-328.

11. Tam SY, Tsai M, Yamaguchi M, Yano K, Butterfield JH, Galli SJ. Expression of functional TrkA receptor tyrosine kinase in the HMC-1 human mast cells. Blood 1997; 90: $1807-1820$.

12. Kassel O, Schmidlin F, Duvernelle C, de Blay F, Frossard N. Up- and down-regulation by glucocorticoids of the constitutive expression of the mast cell growth factor stem cell factor by human lung fibroblasts in culture. Mol Pharmacol 1998; 54: 1073-1079.

13. Kassel O, Schmidlin F, Duvernelle C, Gasser B, Massard G, Frossard N. Human bronchial smooth muscle cells in culture produce stem cell factor. Eur Respir J 1999; 13: 951 - 954.

14. Murase K, Murakami Y, Takayanagi K, Furukawa Y, Hayashi K. Human fibroblast cells synthezise and secrete nerve growth factor in culture. Biochem Biophys Res Commun 1992; 184: 373-379.

15. Cartwright M, Mikheev M, Heinrich G. Expression of neurotrophin gene in human fibroblasts: differential regulation of the brain-derived neurotrophic factor gene. Int J Dev Neurosci 1994; 12: 685-693.

16. Matsuoka I, Meyer M, Thoenen H. Cell-type-specific regulation of nerve growth factor (NGF) synthesis in non-neuronal cells: comparison of Schwann cells with other cell types. J Neurosci 1991; 11: 3165-3177.

17. Furukawa S, Furukawa Y, Satoyoshi E, Hayashi K. Synthesis/secretion of nerve growth factor is associated with cell growth in cultured mouse astroglial cells. Biochem Biophys Res Commun 1987; 142: 395-402.

18. Houlgatte R, Mallat M, Brachet P, Prochiantz A. Secretion of nerve growth factor in cultures of glial cells and neurons derived from different regions of the brain. J Neurosci Res 1989; 24: $143-152$. 
19. Di Marco E, Marchisio PC, Bondanza S, Franzi AT, Cancedda R, De Luca M. Growth-regulated synthesis and secretion of biological active nerve growth factor by human keratinocytes. J Biol Chem 1991; 266: $21718-21722$.

20. Lindholm D, Heumann R, Meyer M, Thoenen H. Interleukin-1 regulates synthesis of nerve growth factor in non-neuronal cells of rat sciatic nerve. Nature 1987; 330: 658-659.

21. Hattori A, Tanaka E, Murase K, et al. Tumor necrosis factor stimulates the synthesis and secretion of biologically active nerve growth factor in non-neuronal cells. J Biol Chem 1993; 268: 2577-2582.

22. Hattori A, Iwasaki S, Murase K, et al. Tumor necrosis factor is markedly synergistic with interleukin 1 and interferon-gamma in stimulating the production of nerve growth factor in fibroblasts. FEBS Lett 1994; 340: $177-180$.

23. Barnes PJ, Chung KF, Page CP. Inflammatory mediators of asthma: an update. Pharmacol Rev 1998; 50: $515-596$.

24. Brodie DH, Lötz M, Cuomo AJ, Coburn DA, Federman EC, Wasserman SI. Cytokines in symptomatic asthmatic airways. J Allergy Clin Immunol 1992; 89: $958-967$.
25. Bonini S, Lambiase A, Bonini S, et al. Circulating nerve growth factor levels are increased in humans with allergic diseases and asthma. Proc Natl Acad Sci USA 1996; 93: 10955 - 10960.

26. Undem BJ, Hunter DD, Liu M, Haak-Fredscho M, Oakragly A, Fischer A. Allergen-induced sensory neuroplasticity in airways. Int Arch Allergy Immunol 1999; 118: $150-153$.

27. Virchow JC, Julius P, Lommatzsch M, Luttmann W, Renz H, Braun A. Neurotrophins are increased in bronchoalveolar lavage fluid after segmental allergen provocation. Am J Respir Crit Care Med 1998; 158: 2002-2005.

28. Barnes PJ, Pedersen S, Busse WW. Efficacy and safety of inhaled corticosteroids. New developments. Am J Respir Crit Care Med 1998; 157: S1-S53.

29. Lindholm D, Hengerer B, Heumann R, Carroll P, Thoenen H. Glucocorticoid hormones negatively regulate nerve growth factor expression in vivo and in cultured rat fibroblasts. Eur J Neurosci 1990; 2: $795-801$.

30. Cartwright M, Martin S, D'Mello S, Heinrich G. The human nerve growth factor gene: structure of the promotor region and expression in L929 fibroblasts. Mol Brain Res 1992; 15: 67-75. 